\title{
Dystrophic calcification of the ankle joint following intra-articular corticosteroid injections
}

\author{
Edward Kim, Michael J Oddy
}

University College London Hospitals NHS Foundation Trust, London, UK

\section{Correspondence to} Michael J Oddy,

mike.oddy@uclh.nhs.uk

Accepted 23 August 2016
CrossMark

\section{DESCRIPTION}

A 17-year-old Caucasian female with the noninfective, inflammatory condition chronic recurrent multifocal osteomyelitis (CRMO) was referred with pain and stiffness in her right ankle. She had previously received seven, non-image-guided intra-articular corticosteroid injections (IACI) over $\sim 5$ years reporting variable clinical benefits and some previous injection flare pain. Examination demonstrated some skin hypersensitivity and local atrophy but no palpable mass or swelling and examination was negative for anterior impingement.

Plain radiographs demonstrated the time-interval development of extra-articular soft-tissue calcification anterior to the ankle joint (figure 1A, B). MRI revealed osteochondral joint degeneration with synovitis. Subsequent treatment over 18 months included two fluoroscopic-guided, $20 \mathrm{mg}$ triamcinolone acetonide IACI using iodine contrast to confirm needle placement (figure 2). Pain control
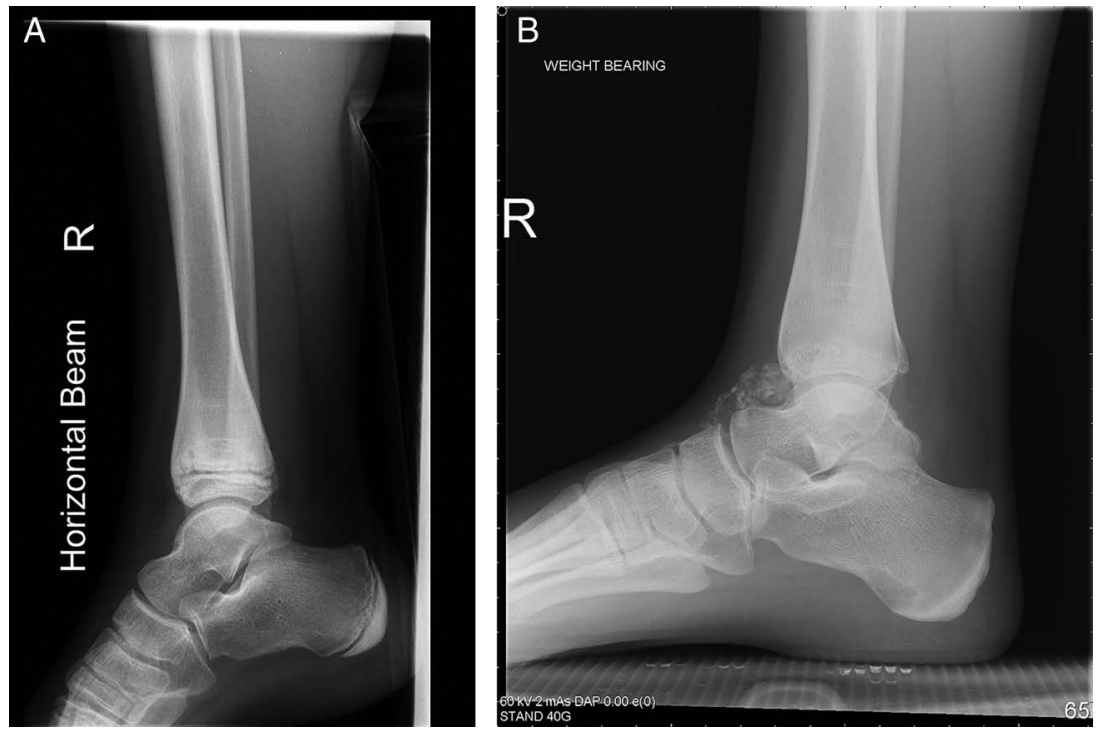

Figure 1(A and B) Lateral radiographs of the right ankle preskeletal and postskeletal maturity over a 5-year interval showing development of dystrophic calcification anterior to the joint.

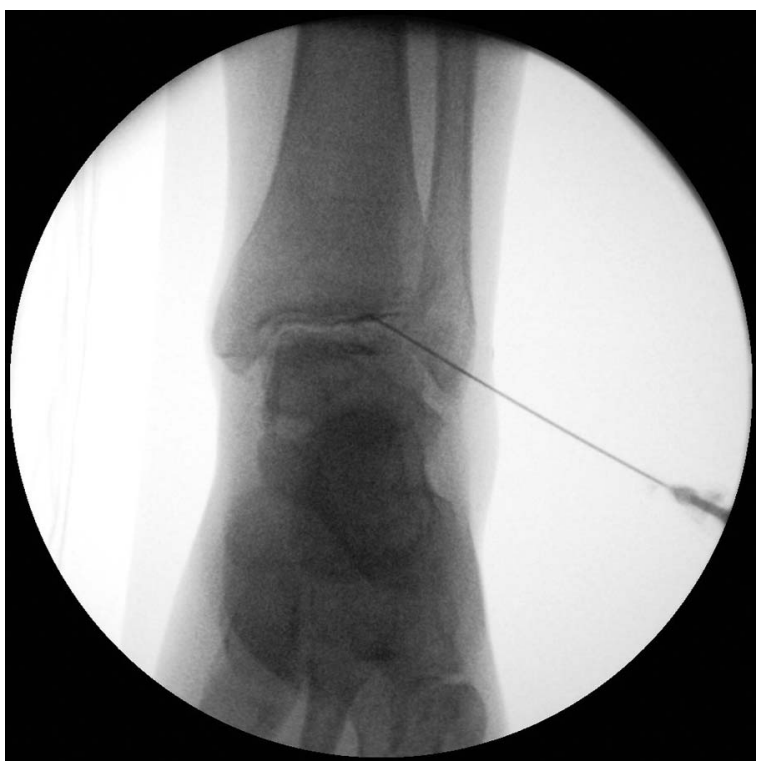

Figure 2 Anteroposterior fluoroscopy image showing the right ankle during intra-articular injection with an iodine contrast arthrogram. 


\section{Learning points}

- Dystrophic calcification is a recognised local side effect of intra-articular corticosteroid injections.

- The ankle joint is associated with one of the lowest accuracies for joint injections although image guidance does not necessarily reduce the local side effects.

- Caution should be exercised when considering repeated corticosteroid injections without appropriately imaging a joint to establish a diagnosis and monitor any local deleterious effects or disease progression.

was achieved without further clinical flare or change in dystrophic calcification.

Lopes et $a l^{1}$ demonstrated the ankle joint had the lowest accuracy for non-image-guided IACI with only $77 \%$ being correctly located. Calcification is a recognised side effect of IACI with rates as high as $50 \%$ reported and can be located in the pericapsular, intracapsular or intra-articular location. ${ }^{2}$ The probable causal mechanism relates to local tissue injury from the needle and low water solubility of the extra-articular corticosteroid with chronic granulomatous inflammation and subsequent dystrophic calcification.

CRMO has very rarely been associated with tumoral calcinosis and the development of large periarticular calcific masses requiring excision so the dystrophic calcification in this case maybe multifactorial. $^{3}$

Competing interests None declared.

Patient consent Obtained.

Provenance and peer review Not commissioned; externally peer reviewed.

\section{REFERENCES}

1 Lopes RV, Furtado RN, Parmigiani L, et al. Accuracy of intra-articular injections in peripheral joints performed blindly in patients with rheumatoid arthritis. Rheumatology 2008:47:1792-4

2 Habib GS, Saliba W, Nashashibi M. Local effects of intra-articular corticosteroids. Clin Rheumatol 2010;29:347-56.

3 Yuksel HY, Yilmaz S, Gurbuzel M. Normal phosphataemic type tumoral calcinosis with chronic recurrent multifocal osteomyelitis: a case report. Acta Orthop Traumatol Turc 2011:45:124-9.

Copyright 2016 BMJ Publishing Group. All rights reserved. For permission to reuse any of this content visit

http://group.bmj.com/group/rights-licensing/permissions.

BMJ Case Report Fellows may re-use this article for personal use and teaching without any further permission.

Become a Fellow of BMJ Case Reports today and you can:

- Submit as many cases as you like

- Enjoy fast sympathetic peer review and rapid publication of accepted articles

- Access all the published articles

- Re-use any of the published material for personal use and teaching without further permission

For information on Institutional Fellowships contact consortiasales@bmjgroup.com

Visit casereports.bmj.com for more articles like this and to become a Fellow 